\title{
Corn-seed Technology: A Study of a New Technology Introduce to Farmer Using Importance Performance Analysis
}

\author{
Renie Oelviani ${ }^{1, *}$, Dewi Sahara ${ }^{1}$, and $R$ Heru Praptana ${ }^{1}$ \\ ${ }^{1}$ Assessment Institute for Agriculture Technology of Central Java
}

\begin{abstract}
The effort to increase hybrid maize in Indonesia is one of the government's crucial programs. Given that multinational companies still master hybrid corn seed technology, farmers need to become independent seed producers with the introduction of technology. Despite the difficulty level of technology, capital and resources are limited. The study aims to analyze the effectiveness of hybrid corn seed technology using the Importance Performance Analysis (IPA) approach in the demonstration plot of maize nurseries in Kendal Regency in 2018-2019. We surveyed at the end of 2019 activities to 33 farmers and 12 assisting officers. The result of this research is the level of interest suitability and technology performance of hybrid corn seeds of 82.61 percent. The average competent value of interest is 4.39 , and the performance value is 3.63 . Three attributes that have a high level of significance, but whose performance is not yet optimal are rouging, detasselling, and machine seed processing. In the future, evaluate the three attributes as an effort to produce quality hybrid maize seeds at the farmer level on a large scale that can be activated.
\end{abstract}

\section{Introduction}

Among programs having been developed by the government is introducing hybrid corn seedling technology at farm level in order to realize advanced, independent, and modern agriculture. Previously, several programs related to corn seed technology have been established to increase productivity of hybrid corn. Among which were community-based composite corn seed breeding conducted in 2004 to 2009 in South Sulawesi, Gorontalo, NTB, NTT, South Kalimantan and Central Sulawesi [1], three-line cross-hybrid corn seed breeding 01 (STJ 01) in South Kalimantan in 2012, 1,000 self-supported seed villages, self- supported seed villages program, and models of self-supported seed zone, which were began in 2016 $[1]$.

In 2018 - 2019, hybrid corn seedling technology started to be introduced in Kendal District of Central Java Province with consideration of high demand for hybrid corn seeds while its price began to be unaffordable for farmers [2], as hybrid corn seeds were controlled by multinational company [3]. However, as the demonstration plot of hybrid corn seedling technology was in progress, its performance was still not fully successful.

\footnotetext{
* Corresponding author: renieoelviani@pertanian.go.id
} 
The hybrid corn seed is one of the main factors in increasing corn production $[4,5]$ Therefore, the purpose to introduce hybrid corn seed technology at farmers' level is to increase income of breeder farmers $[2,6,7]$ as well as to bring farmers closer to the expected hybrid corn seeds [8]. Farmer producing seeds or community-based seeds production might become a supporting system in case of formal seed system and poor seed supply infrastructure bears problems $[9,10]$. In addition to the aforementioned matters, independent corn seed production needs to be done because of limited hybrid corn seeds and prices that are increasingly too expensive for farmers [11].

Nevertheless, the application of hybrid corn seed technology at the farm level requires intensive technical guidance. This technology has not been widely introduced to farmers due to various constraints and problems in seed technology both technical and non- technical ${ }^{11}$, among which are community conditions, unsupportive seed policies, cultivation technology, limited facilities and infrastructure, and marketing. Similar constraints experienced by South African government in the context of community-based seed production scaling are infrastructure, climate, pests, large areas, and isolation distances needed for hybrid corn seed [9].

Considering gaps identified in previous studies, the way to produce high-quality seeds needs to be further studied and evaluated [12]. There are various methods and criteria for evaluation or assessment, one of which is the evaluation criteria in assessing policy results including effectiveness, efficiency, adequacy, leveling, responsiveness, and accuracy [13, 14]. In this case, the criterion used is to measure the effectivenessof whether the hybrid corn seed technology introduced to farmers has met the interests/expectations of farmers in accordance with the objectives achieved.

Given the description and findings of the previous researches, the purpose of this study was to analyze the effectiveness of hybrid corn seed technology introduced to farmers through a hybrid corn seedling demonstration plot using Importance Performance Analysis (IPA) approach.

\section{Research Methods}

The study, involving 33 farmers and 12 assistant officers, was conducted in 2019 in Wirosari Village, Patean Sub-District, Kendal Regency where a demonstration plot of implementation of the Bima Uri 20 hybrid corn seed technology and its supporting attributes was carried out. Technological components and their accompanying attributes consisted of land preparation, use of male and female parents of seeds maize, fertilizing, rouging, detasailing, harvesting, processing of crop yields by machine, and sorting ofcob.

Importance Performance Analysis (IPA) method was used to measure the effectiveness of the introduced Bima Uri 20 hybrid corn seed technology. Primary data collection from cooperating farmers, existing farmers, and assistant officers was carried out in December 2019 through interviews using a structured questionnaire.

Stages of the application of the Natural Sciences method [15] are (1) Data assessment from questionnaire of 45 respondents, (2) Level of Conformity (TKi) between the level of performance and importance. The formulation is written as follows:

$$
T k i=\frac{x i}{100 \%} \times y i
$$

Information:

$T k i=$ Conformity level of the respondent

$x i=$ Score of the performance/satisfaction level

$y i \quad=$ Score of the importance assessment 
(3) Calculation of average performance $(X)$ and importance (y) of all respondent using -the formula:

Information:

$$
\bar{y} \dot{x}=\Sigma \frac{x i}{y}=\Sigma \frac{\hat{y} 1}{\eta}
$$

$\dot{\mathrm{x}} \quad=$ Average score of performance level

$\bar{y} \quad=$ Average score of importance level

$\Sigma x i \quad=$ Number of performance levelscores

$\Sigma \mathrm{Yi}=$ Number of importance levelscores

$\mathrm{N} \quad=$ Number of respondents (45)

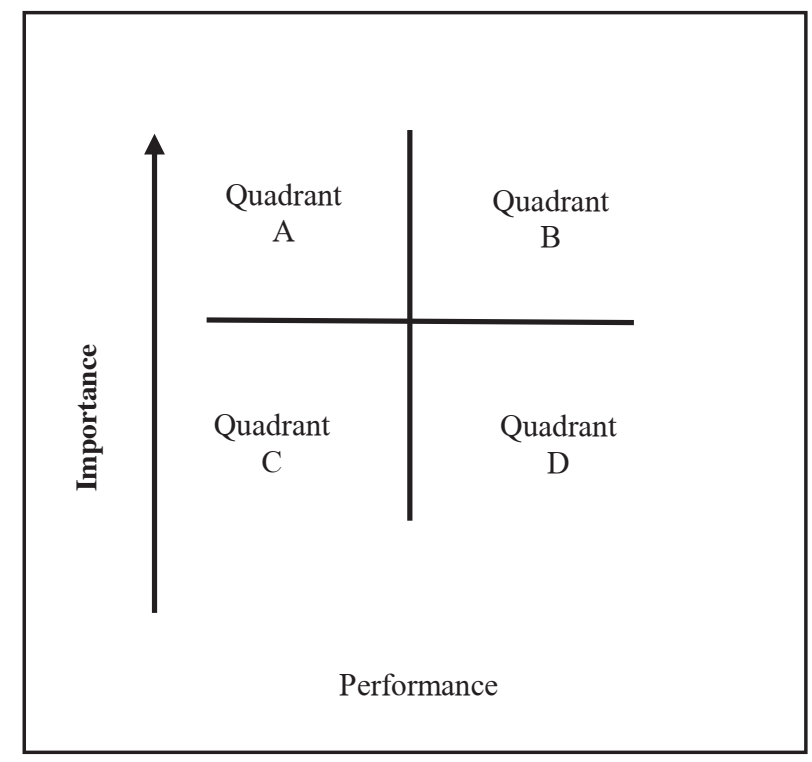

Fig. 1. Cartesius Diagram [16]

Information:

(1) Quadrant A (Main Priority): The quadrant contains factors that are considered critical by customers, but not by following per under customer expectations (the level of satisfaction obtained is still low).

(2) Quadrant B (Maintain Achievement): The quadrant contains factors that are considered important, and are in accordance with what they feel. The level of satisfaction is relatively higher.

(3) Quadrant C (Low Priority): The quadrant contains factors that are considered less specific and infect their performance is not too offer

(4) Quadrant D (Exaggerated): The Quadrant contains factors that are considered less important and considered too excessive.

\section{Results and Discussion}

In Central Java Province, demonstration of hybrid corn seedling technology from upstream to downstream in Kendal Regency was the first conducted at the farm level. Demonstration activities including technology dissemination consisted of planting preparation, planting, looking after, harvesting, post-harvesting, distribution, and marketing. This dissemination was carried out following Kendal Regency government's request to meet the limited needs of hybrid corn seed produced by Agricultural Research Agency available on the market [8]. 


\subsection{Effectiveness of Bima Uri 20 Hybrid Corn Seed Technology}

The IPA analysis showed that the importance and the performance of the attributes associated with the effectiveness of Bima Uri 20 hybrid corn seedlings from upstream to downstream varied, which could be described as follows:

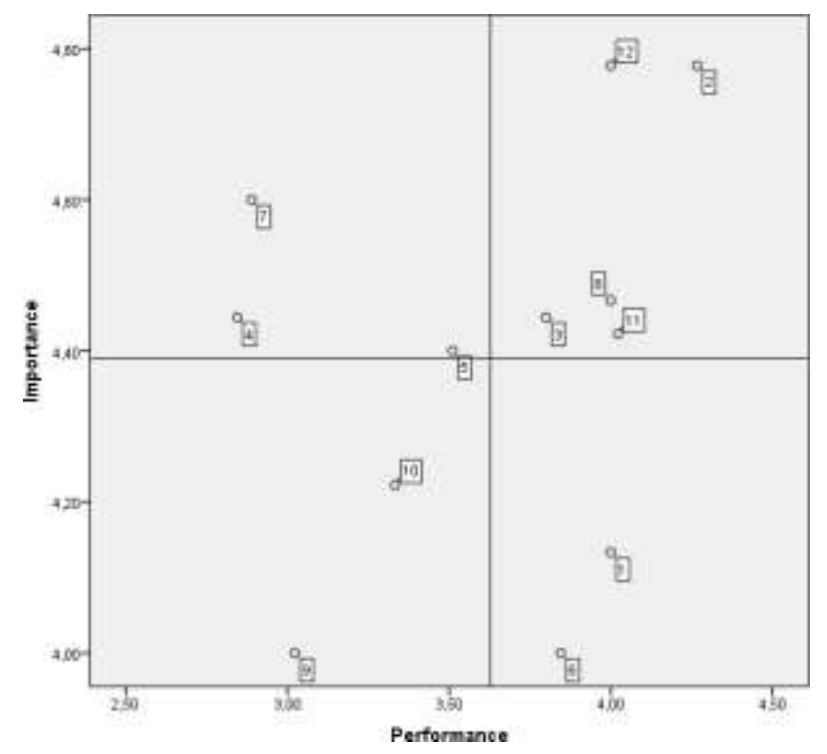

Fig. 2. Quadrant of IPA effectiveness of Hybrid Corn Seed Technology

Note: (1) Land preparation; (2) Use of seeds; (3) Fertilization; (4) Rouging; (5) Detaselling;

(6) Harvesting; (7) Processing seed by machine; (8) Manual seed processing; (9) Sorting cobs;

(10) Extension; (11) Demonstration plot; (12) Field meeting

Figure 1 shows that three attributes having a high level of importance but have not been maximized performance are rouging, detaselling, and seeds processing by machine (Quadrant A). The value of rouging, detaselling, and seeds processing by machineis 4.44, 4.40 , and 4.47 , respectively for the importance, yet the performance of farmers in these three attributes is still low at 2.84, 3.51, and 2.89, respectively (Table 1).

Rouging and detaselling were relatively new techniques for farmers; in fact, those attributes significantly affect productivity of hybrid corn seeds [15,17]. Rouging is carried out to select seeds in order to maintain seeds purity produced [6,18]. Meanwhile, detaselling treatment results is very significant, because flow of energy in flower formation is diverted to growth and development of seeds or cobs, as proven by an observation that weight of sample cob per plot is 720 gr, of sample maize grain per plot is $583 \mathrm{gr}$, and of sample cob per plot is 7,049 gr [19]. On the other hand, seeds processing using machine had not helped farmers due to limited knowledge of farmers regarding mechanization of corn dryer available. 
Table 1. Scoring Rating Effectiveness of Hybrid Corn Seed Technology with IPA Analysis

\begin{tabular}{|c|c|c|c|c|c|c|}
\hline \multirow[t]{2}{*}{ Attribute } & \multicolumn{3}{|c|}{ Importance } & \multicolumn{3}{|c|}{ Performance } \\
\hline & $\Sigma \hat{\mathbf{y}}$ & $\mathbf{n}$ & $\hat{\mathbf{y}}$ & $\Sigma x i$ & $\overline{\mathbf{N}}$ & $\overline{\mathbf{X}}$ \\
\hline 1 Land preparation & 186 & 45 & 4.13 & 180 & 45 & 4.00 \\
\hline 2 Use of seeds & 215 & 45 & 4.78 & 192 & 45 & 4.27 \\
\hline 3 Fertilizing & 200 & 45 & 4.44 & 171 & 45 & 3.80 \\
\hline 4 Rouging; & 200 & 45 & 4.44 & 128 & 45 & 2.84 \\
\hline 5 Detaselling & 198 & 45 & 4.40 & 158 & 45 & 3.51 \\
\hline 6 Harvesting & 180 & 45 & 4.00 & 173 & 45 & 3.84 \\
\hline 7 Seeds Processing by machine & 207 & 45 & 4.60 & 130 & 45 & 2.89 \\
\hline 8 Manually process seeds & 201 & 45 & 4.47 & 180 & 45 & 4.00 \\
\hline 9 Sorting cobs & 180 & 45 & 4.00 & 136 & 45 & 3.02 \\
\hline 10 Extension & 190 & 45 & 4.22 & 150 & 45 & 3.33 \\
\hline 11Demplot & 199 & 45 & 4.42 & 181 & 45 & 4.02 \\
\hline 12 Field Meeting & 215 & 45 & 4.78 & 180 & 45 & 4.00 \\
\hline Total & & & 52.69 & & & 43.53 \\
\hline Number of attributes & & & 12 & & & 12 \\
\hline$\hat{\mathrm{Y}}$ & & & 4.39 & & & 3.63 \\
\hline
\end{tabular}

Source: Primary data processed, 2019

Quadrant B exhibited attributes that were considered important by farmers and had high performance. These attributes were the use of seeds, fertilizing and processing seeds manually, demonstration plots, and field meetings. The results indicated that these attributes were appropriate and expected by farmers so that the level of satisfaction they perceive was relatively high. The importance values of each attribute was $4.78,4.44,4.47,4.42$, and 4.78, respectively while the performance value of each attribute was $4.27,3.80,4.4,4.02$, and 4.00 ,respectively.

In fact, farmers' confidence in hybrid corn seeds was very high as shown by a survey conducted in several maize centers in Central Java that the result is 92.3\% [19]. In this case, among the three attributes, field meetings and demonstration plots were the determinants of the technology introduction because these two attributes provide opportunities for farmers and community to see, observe, and study the implementation of hybrid corn seed innovation. Farmers will be encouraged to adopt technology if there is a balance of facilities obtained such as knowledge, resources, and access to consulting service s[20]. The demonstration plot has been proven effective in increasing the production of agricultural commodities, especially for farmers who are not familiar with the technology/ and have the opportunity to adopt it [21].

Cob sorting and extension were attributes that had a relatively low level of importance and performance (quadrant C). Farmers considered this attribute as they usually did, so farmers considered this attributes not important. This was indicated by the importance and the performance values of each of which were sorting cobs of 4.0 and 3.02, respectively, extension is 4.22 and 3.33, respectively. The introduction of the seed technology is a means of effectively transferring knowledge horizontally to other farmers and vertically through extension agents, research institutions, and private sectors so that if it is implemented maximally, technology will be transferred to other farmers optimally [22].

In quadrant $\mathrm{D}$, land preparation and harvesting were attributes having relatively good performance but low importance. The values of the importance and the performance of each of these attributes were 4.13 and 4.0 and 4.00 and 3.8, respectively. Both of these attributes were activities routinely carried out by farmers and so farmers considered it as no need to be 
treated specially. In this case, land preparation is very essential in corn seed technology, while farmers are accustomed to planting without tillage in the cultivation of corn for consumption [20]. Harvest shall be done on time i.e. when the seeds have reached ripe physiology because the level of ripe influences seeds germination and vigor [12].

\section{Conclusion}

The effectiveness of Bima Uri 20 hybrid corn seed technology from upstream to downstream still varies in terms of its importance and performance. Three attributes having a high level of importance but have not been maximized performance are rouging, detaselling, and seeds processing by machine. Thus, these three attributes must be further evaluated so that sustainability in the effort to produce quality corn seeds at the farm level on a broader scale can be achieved.

\section{Reference}

1. R. Arief dan Muhammad Taufiq Ratule, in Posiding Semin. Nas. Serealia (Maros, 2015), pp. 516-524.

2. M. Yasin, in Semin. Nas. Serealia (Balit Serealia Badan Litbang Pertanian, Maros, 2013), pp. 155-161.

3. V. Darwis, Anal. Kebijak. Pertan. 16, 59 (2018).

4. L. Kadar, H. Siregar, E. Intan, and K. Putri, Inform. Pertan. 25 No 2, 215 (2016).

5. Adri, Mildaerizanti, and Suharyon, J. Ilm. Ilmu Terap. Univ. Jambi 3, 138 (2019).

6. P. M. Sari, M. Surahman, and C. Budiman, Bul. Agrohorti 6, 412 (2018).

7. R. A. Fischer and D. J. Connor, F. Crop. Res. 222, 121 (2018).

8. B. O. Asante, O. Temoso, K. N. Addai, and R. A. Villano, Agric. Syst. 176, 102650 (2019).

9. R. Oelviani, H. Praptana, and S. Jauhari, in Kesiapan Sumber Daya Pertan. Dan Inov. Spesifik Lokasi Memasuki Era Ind. 4.0 (IAARD Press, Bogor, 2019), pp. 185-190.

10. J. Alwang, E. Gotor, G. Thiele, G. Hareau, M. Jaleta, and J. Chamberlin, Agric. Syst. 172, 16 (2019).

11. M. M. Afidchao, C. J. M. Musters, A. Wossink, O. F. Balderama, and G. R. De Snoo, NJAS - Wageningen J. Life Sci. 70-71, 113 (2014).

12. S. Lestari, J. RP, and A. Sumiati, J. Akses Pengabdi. Indones. 1, 9 (2017).

13. L. Bertilsson, K. Wiklund, I. de Moura Tebaldi, O. M. Rezende, A. P. Veról, and M. G. Miguez, J. Hydrol. 573, 970 (2019).

14. Sudjindro, Bul. Tanam. Tembakau, Serat Miny. Ind. 1, 92 (2016).

15. R. Hendayana, Persepsi \& Adopsi Teknologi Teori Dan Praktek Pengukuran (2014).

16. A. Das and T. Basu, Ecol. Indic. 114, 106274 (2020).

17. P. Sugiarta, I. G. Ambarawati, and I. G. S. Adi Putra, J. Manaj. AGRIBISNIS (Journal Agribus. Manag. 5, 34 (2017).

18. B. N. Swamy, N. K. Hedau, G. V. Chaudhari, L. Kant, and A. Pattanayak, Sci. Hortic. (Amsterdam). 222, 175 (2017).

19. A. Pratama, Studi Pengelolaan Tanaman Pada Produksi Benih Jagung Hibrida Di PT Dupont Indonesia, Malang (Bogor, 2011).

20. W. Li, B. Clark, J. A. Taylor, H. Kendall, G. Jones, Z. Li, S. Jin, C. Zhao, G. Yang, C. 
Shuai, X. Cheng, J. Chen, H. Yang, and L. J. Frewer, Comput. Electron. Agric. 172, 105305 (2020).

21. M. A. Ra, I. Erdiansyah, and I. Khoir, Agritop J. Imu - Ilmu Pertan. 108 (2013).

22. 2. R. Oelviani, S. Catur, H. Kurnianto, and S. Jauhari, in Introd. Teknol. Pertan. Dalam Pendampingan Berbas. Kaw., edited by M. Mardiharini, S. Siti, A. Yowita, V. Hanifah, and N. Afaf (IAARD Press, Bogor, 2019), pp. 59-68. 